\title{
Management of a lower lip avulsion injury due to a human bite
}

\author{
Kristian G Malpass BSc, Ronald M Zuker MD FRCSC FACS FAAP, Meir Cohen MD FRCSC \\ The Hospital for Sick Children, Toronto, Ontario
}

\section{KG Malpass, RM Zuker, M Cohen. Management of a lower lip avulsion injury due to a human bite. Can J Plast Surg 2000;8(5):189-192.}

\begin{abstract}
The present case report illustrates the management of an avulsion involving two-thirds of the lower lip. An unsuccessful attempt at microsurgical replantation led to a trial of composite tissue engraftment. Ultimately, the tissue sloughed, and after minimal debridement, the defect was treated by direct approximation of mucosa, muscle and skin. The treatment decisions made in caring for this injury show the challenge of microsurgical tissue replantation, the unpredictability of the composite graft and the benefit of having enough tissue to consider direct tissue approximation. Clearly, lips are worth every attempt at preservation, given their functional, cosmetic and psychological importance.
\end{abstract}

Key Words: Avulsion; Composite graft; Human bite; Lip

\section{Traitement de l'avulsion de la lèvre inférieure due à une morsure d'humain}

RÉSUMÉ : Voici le traitement accordé à l'avulsion des deux tiers de la lèvre inférieure. Une réimplantation infructueuse par la microchirurgie a mené à une tentative de greffe à l'aide d'un tissu composite. Le tissu a fini par se détacher et, après un léger débridement, la déchirure a été corrigée par rapprochement de la muqueuse, des muscles et de la peau. Les décisions relatives au traitement montrent les difficultés liées à la réimplantation de tissus par la microchirurgie, le caractère imprévisible des greffes faites à l'aide de tissus composites et l'avantage d'avoir suffisamment de tissu pour envisager l'affrontement des plans. Nul doute que les lèvres valent la peine qu'on ait recours à tous les moyens possibles pour les préserver, compte tenu de leur importance fonctionnelle, esthétique et psychologique.

L ip reconstruction may be required as a result of facial trauma, infection, congenital deformities or removal of neoplastic lesions. Human bite wounds of the face, specifically the lips, are believed to be uncommon in North America because lips are associated with affectionate gestures and activities. However, lip avulsion injuries occur with increased frequency in territories where lips are not used for kissing and instead become a target of aggressive behaviour. Iregbulem (1) reported that human lip bites treated in Nigerian hospital clinics comprised $1.6 \%$ of all visits. Losken and Auchincloss (2) observed that women are frequently responsible for delivering the bite, whereas a gender bias was not observed in the target population.

\section{CASE PRESENTATION}

A 17-year-old black man suffered a human bite injury with avulsion of the central two-thirds of the lower lip (Figure 1). The depth of the patient's labial sulcus was reduced by $50 \%$, with the inferior wound edge situated $0.5 \mathrm{~cm}$ superior to the labiomental crease.

The young man found the amputated lip fragment soon after it was bitten off (Figure 2) and held the tissue in the palm of his hand for $30 \mathrm{~min}$. At the first opportunity, the avulsed tissue was wrapped in saline-soaked gauze and placed into an ice-filled plastic bag. Saline-soaked compresses were applied to the raw lower lip to keep the wound moist, relieve the patient of persistent drooling and provide the patient with 


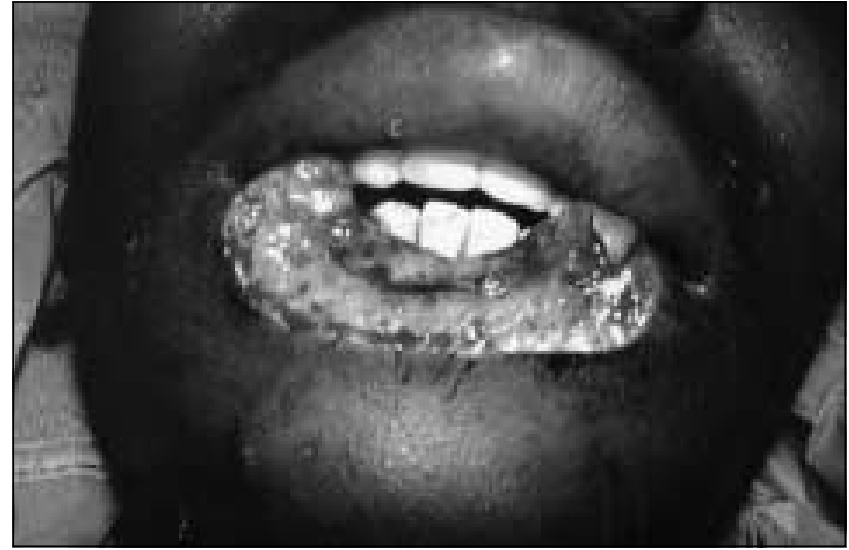

Figure 1) The human bite resulted in the removal of two-thirds of the lower lip span. Significant swelling increased the apparent size of the defect

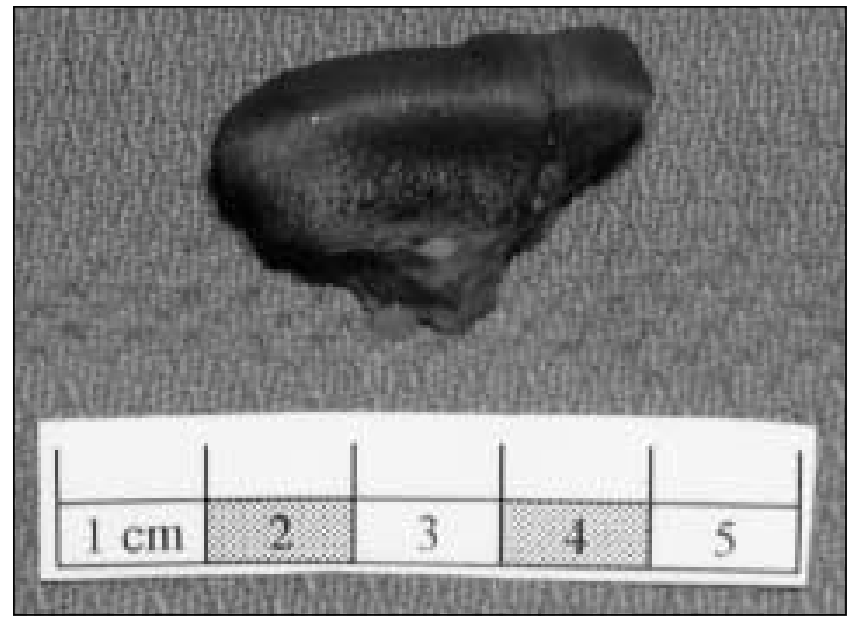

Figure 2) The lip segment recovered by the victim was in reasonable condition. It measured $3 \mathrm{~cm}$ by $2 \mathrm{~cm}$, and the tissue was not expected to take as readily as a composite graft

some pain relief. The wound was not visibly contaminated and failed to show any signs of early infection.

The patient was taken to the operating room $4.5 \mathrm{~h}$ after the injury occurred, to have the tissue microsurgically repaired after minimal debridement.

The nature of the injury and the inherent elasticity of the labial arteries resulted in the blood vessels retracting within the amputated tissue. The labial artery on the left side of the defect was unretrievable.

The ends of the labial artery on the right side of the defect and within the amputated tissue were identified after surgical exploration. The vessel ends were judged to be suitable for reanastomosis. No identifiable veins remained on either border of the amputated tissue; thus, venous anastomosis was not possible. Minimal arterial bleeding from the amputated tissue occurred after arterial anastomosis. There were no immediate difficulties with venous congestion, and heparin was not infused at the replant site.

Judging from the poor arterial flow through the graft, it was thought that the revascularization procedure was un-

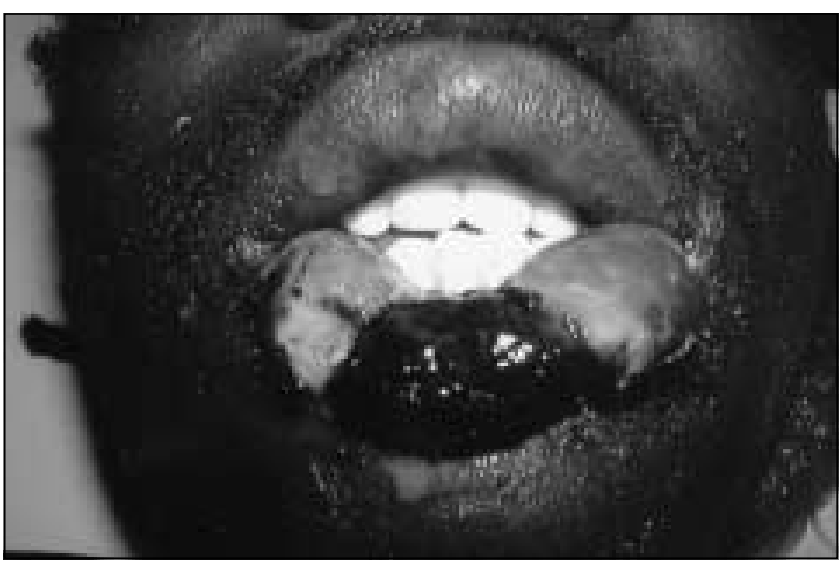

Figure 3) A picture of the patient on the ninth postoperative day. The lower lip did not survive as a composite graft

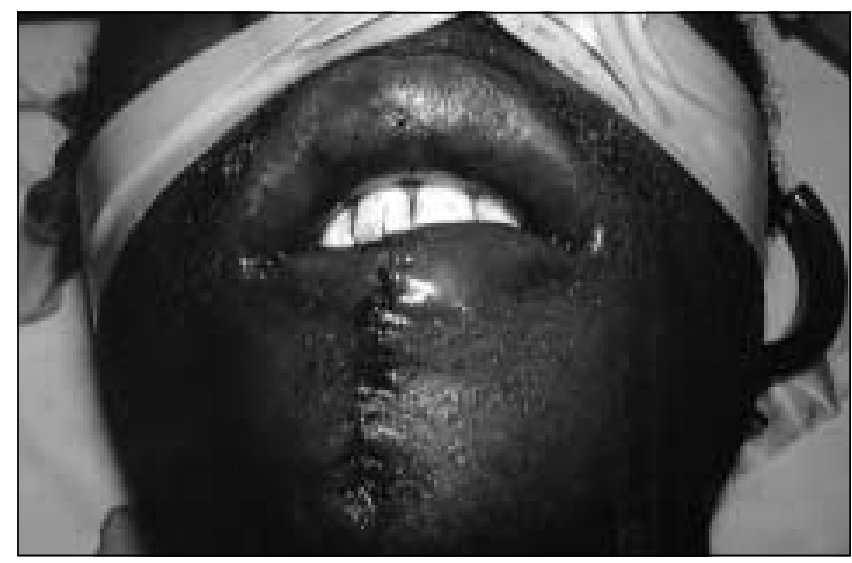

Figure 4) The final procedure, direct approximation of the wound edges, successfully restored the cosmetic and functional deficits

likely to succeed. After $2 \mathrm{~h}$ in the operating room, it was decided that the replant would be done as a composite graft. One day after replantation, piercing the replaced tissue with a sterile 16-guage needle elicited sluggish bleeding. Two days after surgery, this bleeding had ceased. After six days, the replant was cool and soft to touch, dusky to black in colour and slightly malodourous. After nine days, the lip segment easily avulsed with mild tension (Figure 3). Ten days after surgery, the patient returned to the operating room for limited debridement and direct approximation of the wound edges. The immediate result of this final procedure was a tighter, yet approximated lower lip (Figure 4).

\section{DISCUSSION}

The loss of facial tissue, no matter what the cause, has a significant impact on the victim due to inadequacy of both functional and psychological capacity, and the obvious cosmetic defect. Lupo (3) summarized the most important functional aspects of lips to include useful muscle contraction and continuity. These are both essential for oral continence and to prevent chronic drooling. Other characteristics of lip function include appropriate lip laxity (oral gape), sensation, and fa- 
cilitation of mastication, deglutition and speech. Restoring cosmesis for communication through facial expression and to avoid the negative psychological impact of a facial deformity are important issues and should not be overlooked when reconstructing the lip.

The oral cavity hosts aerobic and anaerobic bacteria, giving human bite wounds a tendency toward infection $(4,5)$. Bacteria commonly isolated from infected human bite wounds are Streptococcus pyogenes, Staphylococcus aureus, Proteus vulgaris and Pseudomonas aeruginosa. Agrawal et al (6) described these infections as secondary, involving the vulnerable devitalized tissue at the margin of a bite wound. They also suggested that only the clinical presence of infection and not the delay of presentation of the patient indicates delayed closure (6). Leaving the wounds for delayed primary closure or healing by secondary intention with planned revision may increase the severity of scarring, deformity and functional impairment.

Restorative options become clear after the wound has been adequately assessed. Information required when evaluating this type of injury includes wound location, size and depth, delay to presentation, condition of the amputated tissue and, if present, the level of contamination. Initial estimation of the defect size is challenging, given the effects of tissue swelling and retraction of the divided and incomplete orbicularis oris. Wound contraction and reduction of swelling reveal a more accurate estimate within four to six days after the injury.

The ideal repair is that which employs lip tissue in the procedure. This approach avoids the difficulties associated with identifying donor tissue of appropriate symmetry, shape, colour, texture and subtle mobility. Replanting the amputated tissue, when appropriate, is the most favourable choice. The options available in replanting tissue include returning the tissue as a composite graft or reanastomosing the blood vessels. James (7) and Walker and Sawhney (8) advocate microsurgical vessel repair and replantation for a more reliable outcome. Identification and repair of the stretch-injured, retracted labial arteries may be difficult; however, the fragile veins are often damaged beyond repair and provide the greatest technical challenge (9). Microsurgical success has been well described in the absence of vein reanastomosis by Witlock et al (9).

In the case where an arterial hook-up is achieved without venous anastomosis, a number of pharmacological and surgical techniques may be used to reduce damaging venous congestion. Establishing venous drainage is critical for tissue survival, especially three to five days after surgery, while neovascularization from surrounding tissues is established (10).

Pharmacological methods of relieving harmful venous congestion include the chemical leech (topical heparin, heparin infusion and a wydase/heparin infusion [9]), systemic acetylsalicylic acid, systemic antispasmodic and low molecular weight dextran $(11,12)$.

Surgical techniques available include arteriovenous (A-V) anastomosis (11), A-V fistula (12), subcutaneous flap (13) and bloodletting through pinpricks and medical leech therapy
$(14,15)$. A benefit of avoiding chemical or medical leeches is the reduced need for compensatory blood transfusion (15).

If replantation is successful, the patient may expect a return of sensation two years after surgery, muscle function after one year and a good tissue match (16). Walker and Sawhney (8) achieved a return of protective sensibility in $92 \%$ of patients who had composite lip grafts and orbicularis oris function in $77 \%$ of the same patients, while $100 \%$ attained oral competence. As described in major tissue revision procedures such as the Estlander flap, reinervation is secondary to ingrowth of nerve fibres at tissue interfaces (16).

The composite graft technique is widely reported as being unpredictable and often results in failure $(12,17)$. However, it is reasonable to use this alternative when microsurgical replantation is inappropriate or fails. Composite grafts have been used successfully in cases where the piece of tissue to be replaced is small (18). However, Troques and Danan (19) described a case of a large lower lip segment measuring 25 by $15 \mathrm{~mm}$ that survived as a composite graft. It is believed that large lip replants require at least one arterial hook-up for survival. The study by Walton et al (18) showed successful microsurgical replantation of lip segments with an average area of $11.2 \mathrm{~cm}^{2}$. Therefore, after a failed microsurgical procedure, the best scenario for the patient featured in the present case report would have been the tissue surviving as an augmented composite. Unfortunately, composite graft failure became clear when the tissue separated from the wound bed on the eighth postoperative day.

The definitive procedures in this case were debridement and direct approximation. However, this approach is generally not appropriate in situations where the defect is greater than one-third of the lower lip span (20). The resulting tight lower lip that impedes oral access is the reason for this guideline. Moreover, a taut lower lip reduces the ability to access food in the labial sulcus. Black people generally have a left to right oral commissure span that is $7 \mathrm{~mm}$ greater than that in white people (2). This increased lip span gives the surgeon more leeway for resection and suturing when faced with defects that span greater than one-third of the lower lip.

\section{CONCLUSIONS}

The present case report shows the successful management of a lower lip avulsion in a 17-year-old black man with the loss of two-thirds of the lower lip span. Replantation with one arterial anastomosis was attempted in the absence of venous hook-up. Inadequate arterial inflow resulted in a trial of the replant as a composite graft. When the graft failed, limited debridement and direct approximation of the tissues were attempted with success.

\section{REFERENCES}

1. Iregbulem LM. Human bite losses of the lower lip. Plast Reconstr Surg 1979;64:811-5.

2. Losken HW, Auchincloss JA. Human bites of the lip. Clin Plast Surg 1984;11:773-5.

3. Lupo G. Our experience with lip reconstruction. Clin Plast Surg 1984;11:619-35. 
4. Earley MJ, Bardsley AF. Human bites: A review. Br J Plast Surg 1984;37:458.

5. Goldstein EJ, Caffee HE, Price JE, et al. Human bite infections. Lancet 1977;ii: 1290.

6. Agrawal K, Mishra S, Panda KN. Primary reconstruction of major human bite wounds of the face. Plast Reconstr Surg 1992;90:394-8.

7. James NJ. Survival of large replanted segments of upper lip and nose, a case report. Plast Reconstr Surg 1976;58:623.

8. Walker JC, Sawhney OP. Free composite lip grafts. Plast Reconstr Surg 1972;50:142-6.

9. Witlock MR, O'Hare PM, Sunders R, et al. The medicinal leech and its use in plastic surgery: A possible cause for infection. Br J Plast Surg 1983;36:240.

10. Miller TA. Wound contraction as treatment of dog bite avulsions of the lip. Ann Plast Surg 1987;19:42.

11. Barnett GR, Taylor GI, Mutimer KL. The "chemical leech": Intra-replant subcutaneous heparin as an alternative to venous anastomosis - Report of three cases. Br J Plast Surg 1989;42:556.

12. Jeng S, Wei F, Noordhoff MS. Successful replantation of a bitten-off vermilion of the lower lip by microvascular anastomosis: case report. J Trauma 1992;33:914-6.

13. Poletti LS. Subcutaneous flap as an alternative to venous anastomosis in replantation surgery. Plast Reconstr Surg 1981;68:233.

14. Husami TW, Cervino AL, Pennington GA, Douglas, BK. Replantation of an amputated upper lip. Microsurgery 1992;13:155.

15. Jeng S, Wei F, Noordhoff MS. Replantation of amputated facial tissues with microvascular anastomosis. Microsurgery 1994;15:327-33.

16. Smith JW. The anatomical and physiologic acclimatization of tissue transplanted by the lip switch technique. Plast Reconstr Surg 1960;26:40.

17. Grabb WC, Dingman RO. The fate of amputated tissue of the head and neck following replacement. Plast Reconstr Surg 1972;49:28.

18. Walton RL, Beahm EK, Brown RE, et al. Microsurgical replantation of the lip: a multi-institutional experience. Plast Reconstr Surg 1998;102:358-68.

19. Troques R, Danan D. [Replantation of a free lip shred following a human bite]. Nouv Presse Med 1981;10:2831-2.

20. Hamilton MM, Branham GH. Concepts in lip reconstruction. Otolaryngol Clin North Am 1997;30:593-606. 